the end of each clearance period. The duration of clearance periods was 10 to 15 minutes.

Heparinized venous blood was collected near the midpoint of each period for estimation of plasma inulin and C5 or C6. Protein precipitation was with cadmium sulphate (Goldring and Chasis, 1944), and inulin was estimated by the method of Roe et al. (1949). The plasma and urine methonium levels were estimated on the nictitating membrane preparation, in the cat, by close arterial injection into the superior cervical ganglion. The peripheral end of the cut cervical sympathetic nerve was stimulated continuously to give a constant and maximum retraction of the membrane ; untreated plasma and diluted urine were delivered to the superior cervical ganglion by a retrograde injection into the external carotid, which was ligated peripherally. The ganglionic block produced by methonium activity decreased the retraction of the nictitating membrane, and the extent of this relaxation was calibrated by injection of standard concentrations of methonium compounds. A description of this biological assay will be published shortly by Dr. W. D. M. Paton, who was very generous in teaching us the technique.

\section{Results and Comments}

The results are shown in the Table. The clearance figures are the average of two or three periods.

\section{The Simultaneous Renal Clearances of Hexamethonium or} Pentamethonium Bromide and Inulin

\begin{tabular}{|c|c|c|c|c|c|c|}
\hline & \multirow{2}{*}{ Anaesthetic } & \multirow{2}{*}{ 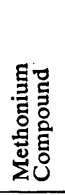 } & \multirow{2}{*}{ 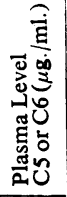 } & \multicolumn{2}{|c|}{$\underset{(\mathrm{ml} . / \mathrm{min} .)}{\text { Renal Clearance }}$} & \multirow{2}{*}{$\begin{array}{l}\text { C5 or } \mathrm{C} 6 \\
\text { Inulin } \\
\text { Clearance } \\
\text { Ratio }\end{array}$} \\
\hline & & & & C5 or C6 & Inulin & \\
\hline 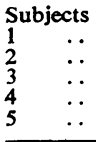 & $\begin{array}{l}\text { None } \\
\text { Ether } \\
\text { Cÿclopropane }\end{array}$ & $\begin{array}{l}\text { C5 } \\
\text { C6 } \\
\text { C5 } \\
\text { C5 } \\
\text { C5 }\end{array}$ & $\begin{array}{l}7 \cdot 2 \\
5 \cdot 3 \\
5 \cdot 1 \\
3 \cdot 6 \\
5 \cdot 1\end{array}$ & $\begin{array}{r}51 \\
97 \\
121 \\
154 \\
62\end{array}$ & $\begin{array}{r}57 \\
94 \\
97 \\
110 \\
61\end{array}$ & $\begin{array}{l}0.9 \\
1.0 \\
1.2 \\
1.4 \\
1.0\end{array}$ \\
\hline Average & & & & & & $1 \cdot 1$ \\
\hline $\begin{array}{ll}\text { Cats } & \\
1 & \ldots \\
2 & \ldots \\
3 & \ldots\end{array}$ & $\begin{array}{l}\text { Pentobarbitone } \\
\text { sodium } \\
\text { Chloralose }\end{array}$ & $\begin{array}{l}\text { C6 } \\
\text { C6 } \\
\text { C6 }\end{array}$ & $\begin{array}{l}2 \cdot 0 \\
3.6 \\
4 \cdot 6\end{array}$ & $\begin{array}{r}7.8 \\
10.8 \\
5.7\end{array}$ & $\begin{array}{r}6.8 \\
10.0 \\
4.7\end{array}$ & $\begin{array}{l}1 \cdot 1 \\
1 \cdot 1 \\
1 \cdot 2\end{array}$ \\
\hline Average & & & & & & $1 \cdot 1$ \\
\hline \begin{tabular}{ll}
\multicolumn{2}{l}{ Rabbits } \\
1 & $\ldots$ \\
2 & $\ldots$ \\
3 & $\ldots$ \\
4 & $\ldots$ \\
\end{tabular} & $\begin{array}{c}\text { Pentobarbitone } \\
\text { sodium } \\
\text { ", } \\
, "\end{array}$ & $\begin{array}{l}\text { C6 } \\
\text { C6 } \\
\text { C6 } \\
\text { C6 }\end{array}$ & $\begin{array}{r}3.0 \\
12.5 \\
5.9 \\
6.4\end{array}$ & $\begin{array}{l}3.2 \\
7.4 \\
6 \cdot 3 \\
5 \cdot 0\end{array}$ & $\begin{array}{l}4 \cdot 5 \\
5 \cdot 3 \\
6 \cdot 4 \\
3 \cdot 4 \\
\end{array}$ & $\begin{array}{l}0.7 \\
1.6 \\
1.0 \\
1.4 \\
\end{array}$ \\
\hline A verage & & & & & & $1 \cdot 2$ \\
\hline
\end{tabular}

The average methonium : inulin clearance ratio is 1.1 in man and the cat and 1.2 in the rabbit. It is clear from these ratios that the renal excretion of $\mathrm{C5}$ and $\mathrm{C6}$ is mainly due to filtration, with some minimal excretion by the tubules. It follows, therefore, that the maintenance dosage of these methonium compounds should be proportionately less in cases in which the glomerular filtration rate is reduced.

\section{Summary}

The mechanism of the renal excretion of hexamethonium and pentamethonium bromide has been studied in man, the cat, and the rabbit by comparing their clearances with the simultaneous clearancé of inulin.
The methonium:inulin clearance ratios were 1.1 to 1.2 , indicating that the renal excretion of these methonium compounds is mainly due to glomerular filtration, with minimal tubular excretion.

\section{REFERENCES}

Goldring, W., and Chasis, H. (1944). Hypertension and Hypertensive Disease. New York

Milne, G. E., and Oleesky, S. (1951). Lancet, 1, 889.

Roe, J. H., Epstein, J. H., and Goldstein, N. P. (1949). J. biol. Chem., 178, 839 .

Zaimis, E. J. (1950). Brit. J. Pharmacol., 5, 424.

\section{Medical Memoranda}

\section{Streptomycin and Friedländer's Bacillus}

This case is of interest because it shows how a bacteriological investigation may be of value in guiding the choice of treatment.

\section{Case Report}

The patient, a middle-aged woman in good general health, had suffered from recurrent attacks of sinusitis in both left and right maxillary antra since 1937, when a left intranasal antrostomy and turbinectomy was performed. This operation was undertaken on the strength of a radiological abnormality found during a search for septic foci to account for a rheumatic episode.

The long-term result of the operation was not wholly successful and a variable amount of discharge had come from the sinuses ever since, with, from time to time, acute attacks of pain, headache, and sometimes fever. These had become more frequent recently, as many as a dozen having occurred during the past two years. The patient habitually treated such attacks with nose drops of a sulphonamide compound, and the acute condition usually cleared up in a few days.

In March, 1950, she developed one of her usual "acute" attacks of sinusitis on the left side. The attack failed to respond to sulphonamide drops, pain and headache remained, and the discharge from the nose became thick and yellow.

On April 17 a left nasal swab was submitted for bacteriological examination and a profuse pure growth of a Friedländer's bacillus was obtained. The organism was nonmotile and capsulated, and had the following biochemical reactions after 24 hours' growth at $37^{\circ}$ C.: Lactose - ; glucose A.G.; mannitol A.G.; sucrose - ; salicin A.G.; dulcitol - ; maltose A.G. ; indole +.

Plate-sensitivity tests were performed, with the following results. Resistant: penicillin, sulphanilamide, sulphacetamide, methyl violet; slightly sensitive: sulphadiazine, phenoxetol ; very sensitive: streptomycin.

On May 3 this organism was still present, and so were the symptoms. Meanwhile the patient had been using inhalants and decongestive drugs and twice-weekly short-wave diathermy had been started, all without effect. Indeed, a brief exacerbation of headache had following each diathermy session.

Treatment by direct attack against the Friedländer's bacillus was then considered. "Aureomycin" and chloramphenicol were not available at the time. Streptomycin was the available drug to which the organism was most sensitive, but it had the disadvantages of being likely to produce rapid development of bacterial resistance if used locally and of involving daily intramuscular injections and possibly toxic side-effects if used systemically. Accordingly it was decided to try first of all the effect of local treatment with phenoxetol, to which the organism showed some sensitivity.

A $2 \%$ solution of phenoxetol in physiological saline was used, a few drops being instilled into the nose four times daily. Unfortunately this solution caused smarting pain 
(perhaps a solution incorporating procaine would have been more satisfactory), and we were surprised to find the patient persevering with its use for several weeks because she was certain that it reduced the amount and thickness of the discharge.

Swabs taken on May 15 while phenoxetol was being used showed Friedländer's bacilli still present but in reduced numbers. After it was discontinued swabs cultured on July 21 again gave a profuse growth of Friedländer's bacilli.

On September 9 the patient was seen by one of us (C. P. M.) at the Metropolitan Ear, Nose, and Throat Hospital. There short-wave diathermy was given daily for a week instead of twice weekly, but no improvement was observed.

On September 16 a course of intramuscular injections of streptomycin was started, $0.5 \mathrm{~g}$. being given twice daily for 22 days as well as the short-wave diathermy. The patient complained of minor toxic symptoms but did not interrupt the treatment.

After a fortnight the nose began to clear, and by the end of the treatment complete relief of symptoms had been obtained. There remained only a very slight mucoid nasal discharge. The patient was free of headache for the first time in seven months. Nasal swabs were examined again on October 16, 26, and 31 and November 8, and no Friedländer's bacilli were isölated. The only organisms present were micrococci. (These, incidentally; were sensitive to streptomycin and so were probably picked up after the end of treatment.)

\section{Comment}

In this case it was well worth while to eradicate the particular infection concerned; and bacteriological tests were of help in indicating which antibacterial substances were likely to be effective. It would be optimistic to suppose that damaged sinuses which have been subject to recurring infection over a period of thirteen years will long remain clear ; it is, however, reasonable to hope that subsequent infections may be with organisms less virulent and more easily dismissed.

$$
\begin{aligned}
& \text { MaIr E. M. Thomas, M.B., Ch.B., } \\
& \text { • B.Sc., D.P.H. } \\
& \text { C. P. Malley, F.R.C.S. }
\end{aligned}
$$

\section{Torsion of Ovarian Cyst in a Newborn Infant}

The occurrence of ovarian cysts and tumours in the newborn is not common, but has from time to time been recorded (Downes, 1921 ; Dodek, 1933 ; Bulfamonte, 1942). There are, however, fairly numerous references in the literature to such cysts in young children, and it is likely that some of these have been present since birth. Torsion of an ovarian cyst at or near the moment of birth is a rare accident in the newborn, and among the many suggested causes of torsion of these cysts the process of birth has not been mentioned. A case similar to the one here described was reported by v. Franque (1900).

\section{Case Report}

A healthy woman aged 19, who had had one previous full-time normal confinement and no abortions, was admitted to hospital in premature labour in the 35th week of her pregnancy. After an easy labour lasting $7 \frac{3}{4}$ hours she was spontaneously delivered of a female infant weighing $4 \mathrm{lb}$. $9 \mathrm{oz}$. $(2,070 \mathrm{~g}$.), the head being delivered in the occipitoposterior position. The baby was active at birth and appeared to be healthy. When it was about 6 hours old it

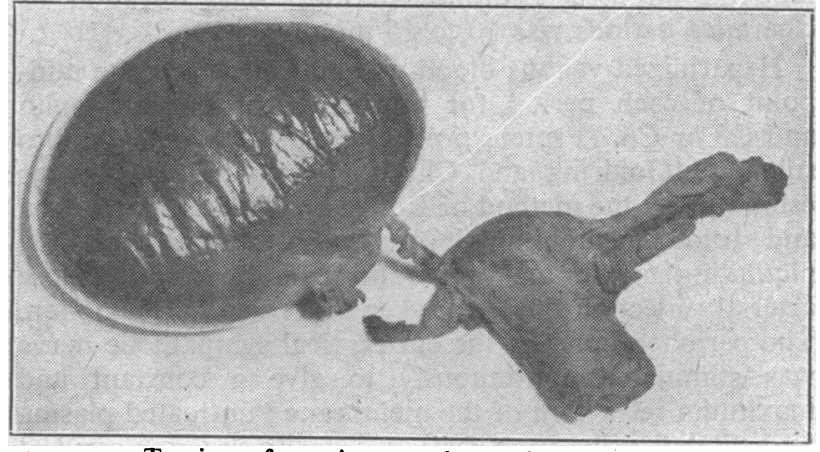

Torsion of ovarian cyst in newborn infant.

was noted to be cyanosed, but no other abnormal physical signs were found. It was nursed in an oxygen tent, but its condition deteriorated and it died 22 hours after birth.

Necropsy showed the presence of a considerable degree of pulmonary atelectasis, and examination of the pelvic viscera disclosed a left-sided ovarian cyst $4 \mathrm{~cm}$. in diameter. No further abnormality was found in the body. The cyst had undergone torsion, there being five complete turns in the pedicle, which consisted of Fallopian tube and mesosalpinx (see illustration). - The left ovary appeared to be completely replaced by the cyst, no ovarian tissue being visible to the naked eye ; the fimbriated end and outer half of the tube had undergone torsion with the cyst.

The cyst was dark purple in colour, and when opened was found to contain thin bloody fluid, but no actual gangrene was present. Histological examination of the cyst wall showed this to consist of fibrous tissue with a cellular lining, but owing to the degree of necrosis it was not easy to classify these cells. A few primordial follicles were visible in the cyst wall. Diagnosis of the type of cyst evidently lay between a cystoma simplex and a follicular cyst, more probably the former.

\section{Comment}

The case described by v. Franque was almost exactly similar to this one; the cyst in his case was $4 \mathrm{~cm}$. in diameter ; the pedicle was twisted three times, and the infant died 18 hours after birth. He considered that it was a follicular cyst. From the degree of necrosis present in the cyst wall in our case and from the clinical condition of the baby it seems likely that torsion of the cyst must have occurred about the time of birth.

We are indebted to Mr. J. McCorquodale for the photograph.

JAMES MaIR, F.R.C.S.Ed., M.R.C.O.G. A. Dick, M.D., B.Sc.

Southern General Hospital, Glasgow.

\section{REFERENCES}

Bulfamonte, J. C. (1942). Amer. J. Surg., 55, 175.

Dodek, S. M. (1933). Amer. J. Obstet. Gynec., 25, 914

Downes, W. A. (1921). J. Amer. med. Ass., 76, 443.

v. Franque, O. (1900). Z. Geburtsh. Gynäk., 43, 257.

One way of alleviating the present $x$-ray film shortage was revealed at an inquiry conducted by the L.C.C. public control committee into the running of the Hammersmith and District Foot Clinic when it was alleged that one of the partners pretended to take photographs when the apparatus was not working (News Chronicle, December 11). After a hearing which lasted nearly nine hours it was decided to revoke the clinic's licence on the grounds that the man was unsuitable to hold a licence. Giving evidence, his woman assistant told the committee that he had taken photographs more than $\mathbf{4 0}$ times without plugging the machine in properly; if a patient asked for a photograph he would wet an old film in the darkroom. 